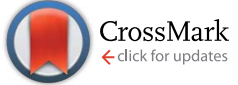

Cite this: RSC Adv., 2017, 7, 9412

Received 5th October 2016

Accepted 10th November 2016

DOI: $10.1039 / c 6 r a 24764 d$

www.rsc.org/advances

\section{Copper salt-catalyzed formation of a novel series of triazole-spirodienone conjugates with potent anticancer activity $\dagger$}

\author{
Linghui Gu, ${ }^{a}$ Peng Wang, ${ }^{a}$ Qiu Zhong, ${ }^{\text {bc }}$ Yuxing Deng, ${ }^{a}$ Jiangping Xie, ${ }^{a}$ Fei Liu, $^{a}$ \\ Fan Xiao, ${ }^{d}$ Shilong Zheng, ${ }^{\text {bc }}$ Yue Chen, ${ }^{e}$ Guangdi Wang ${ }^{\star b c}$ and Ling $\mathrm{He}^{\star a}$ \\ Copper salt-catalyzed oxidative amination resulted in the formation of a novel series of triazole- \\ spirodienone conjugates, 4-triazolyl-1-oxa-4-azaspiro[4,5]deca-6,9-dien-3,8-diones and 4-triazolyl-1- \\ oxa-4-azaspiro[4,5]deca-6,9-dien-8-ones. A single crystal of compound $1 \mathrm{p}$ among them was grown and \\ analyzed by $\mathrm{X}$-ray crystallography. These compounds were evaluated for their antiproliferative activities \\ against MDA-MB-231, HeLa, A549 and MCF-7 cell lines. Most of them showed moderate to high \\ anticancer potency in the four cancer cell lines. The discovery of the triazole-spirodienone conjugates \\ as cytotoxic agents against cancer cells may open up a new field in which these novel small molecules \\ could be further explored as promising anticancer agents.
}

\section{Introduction}

More than one hundred drugs have been approved by the United States Food and Drug Administration (USFDA) for clinical treatment of cancers over the last half century, yet the search for new chemical entities as potential anticancer agents continues in the hope that improved pharmaceutical profiles may come from hitherto unknown molecular structures that encode the keys to greater efficacy and more manageable adverse side effects. Among numerous drug discovery approaches such as high-throughout screening, molecular modeling, and natural compound mimetics, one method may prove effective that takes pharmacophores important in existing anticancer agents on which to rationally design modified structures that may confer a better therapeutic index.

Quinone is a common moiety of numerous biologically active molecules, including natural and synthetic anticancer drugs such as doxorubicin, ${ }^{1}$ mitoxantrone, ${ }^{2}$ andaunorubicin $^{3}$ and mitomycin C. ${ }^{4}$ The role of the quinone moiety

${ }^{a}$ Key Laboratory of Drug-Targeting and Drug-Delivery Systems of the Ministry of Education, Department of Medicinal Chemistry, West China School of Pharmacy, Sichuan University, Chengdu, 610041, China

${ }^{b}$ RCMI Cancer Research Center, Xavier University of Louisiana, New Orleans, LA 70125, USA

'Department of Chemistry, Xavier University of Louisiana, New Orleans, LA 70125, USA ${ }^{d}$ Jiangxi Provincial People's Hospital, Nanchang, 330006, China

${ }^{e}$ Department of Nuclear Medicine Affiliated Hospital, Luzhou Medical College, No. 25 Taiping Street, Luzhou, 646000, P. R. China

$\dagger$ Electronic supplementary information (ESI) available. CCDC 1486522. For ESI and crystallographic data in CIF or other electronic format see DOI: 10.1039/c6ra24764d appears to be important in endowing bioactivities in the molecules ranging from simple small quinones to large complex quinoid systems. ${ }^{5-9}$ Thus the utility of quinonecontaining structures has been extensively explored in search of anticancer drug candidates, leading to an ever increasing library of new promising quinones with anticancer activities. ${ }^{10-16}$ We have previously obtained some quinone derivatives and conjugates as anticancer agents. ${ }^{17,18}$ In another previous work on quinones, ${ }^{19}$ we found that $\mathrm{N}$-sulfonamide spirodienone derivatives (Fig. 1) demonstrated moderate cytotoxic activities against HCT-8, Bel7402, BGC-823, A549 and A2780 cell lines with $\mathrm{IC}_{50}$ values in the range of $1.93-51 \mu \mathrm{M}$.

The introduction of a 1,2,4-trizole ${ }^{20,21}$ ring into molecules has been reported to significantly increase anticancer activity or improve the bioavailability and overall pharmacological profile of a drug candidate. ${ }^{22-26}$ Indeed, clinically proven anticancer drugs $\mathrm{s}^{27,28}$ such as letrozole, vorozole, and anastrozole all contain a 1,2,4-triazole nucleus which is stable to metabolism and acts as an important pharmacophore at the active site of receptors as hydrogen bond acceptor or donor. We hypothesize that conjugating quinones with a 1,2,4-triazole nucleus may generate novel molecular entities with desirable anticancer activities. Therefore, $N$-sulfonamide-spiro-dienones were chosen as the lead compound and triazole-spirodienone conjugates were designed by replacing the sulfonyl functional group with a 1,2,4 (the relative position of ring nitrogen)triazole nucleus (Fig. 1). Herein, we report the synthesis and anticancer evaluation of the designed triazole-spirodienone conjugates: 4-triazolyl-1-oxa-4-azaspiro[4,5]deca-6,9-dien-3,8diones (1) and 4-triazolyl-1-oxa-4-azaspiro[4,5]-deca-6,9-dien-8ones (2). 

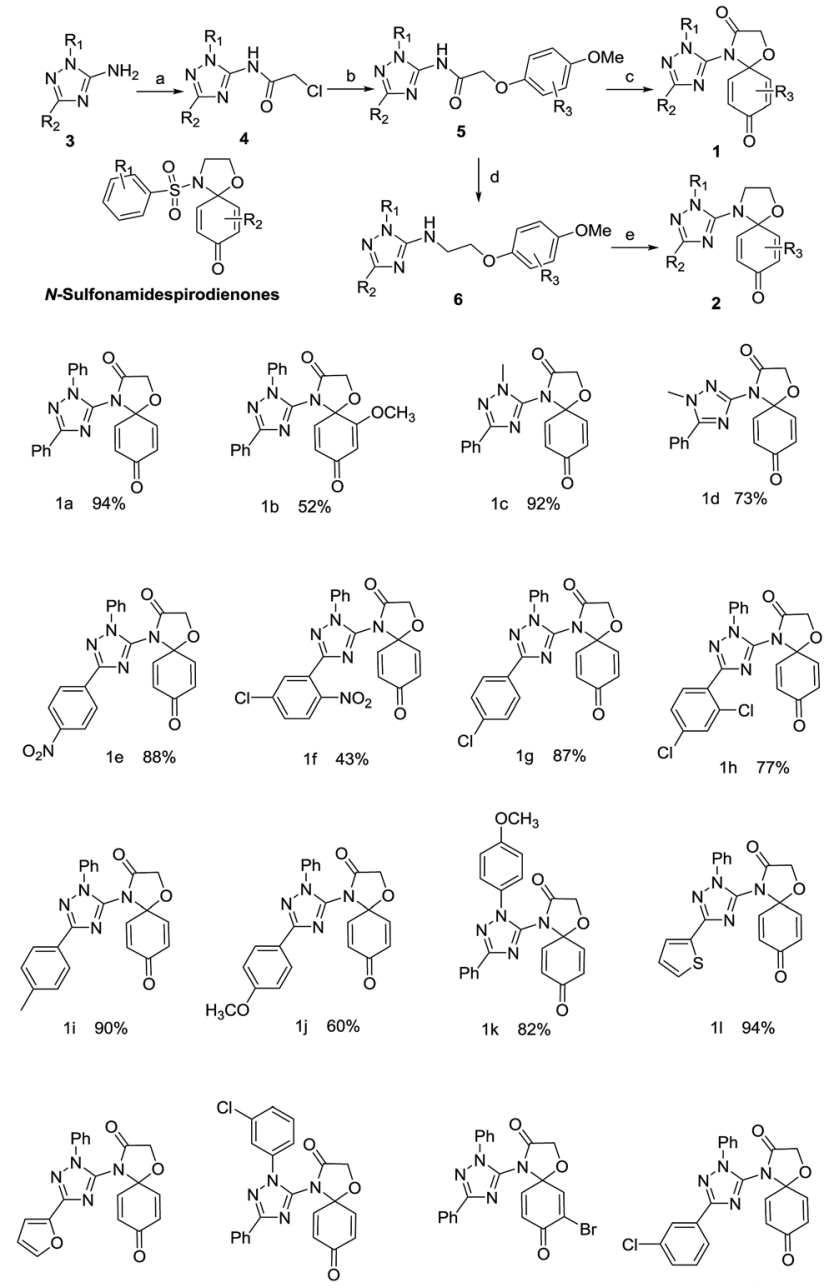

1n $83 \%$

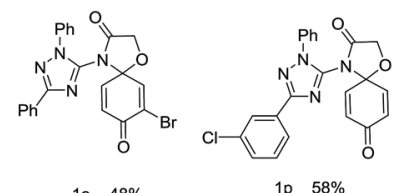

$1 \mathrm{~m} \quad 71 \%$
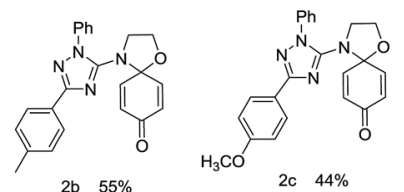

2c $44 \%$

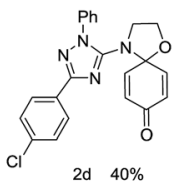

2a $57 \%$
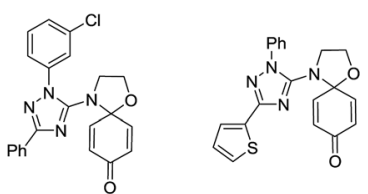

2 g $47 \%$

2h $36 \%$

Fig. $1 \mathrm{~N}$-Sulfonamide spirodienones and synthetic scheme of designed novel triazole-spirodienone conjugates ( 1 and 2). Reagents and conditions: (a) chloroacetyl chloride, $(\mathrm{Et})_{3} \mathrm{~N}, \mathrm{CH}_{2} \mathrm{Cl}_{2}$; (b) $\mathrm{R}_{3}-$ PhONa, DMF; (c) $\left[\mathrm{Cu}\left(\mathrm{CH}_{3} \mathrm{CN}\right)_{4}\right] \mathrm{ClO}_{4}, \mathrm{Phl}\left(\mathrm{CF}_{3} \mathrm{CO}_{2}\right)_{2}, \mathrm{CH}_{2} \mathrm{Cl}_{2}, \mathrm{rt}$; (d) $\mathrm{LiAlH}_{4}, \mathrm{AlCl}_{3}$; (e) $\mathrm{Cu}\left(\mathrm{CF}_{3} \mathrm{SO}_{2}\right)_{2}, \mathrm{Phl}\left(\mathrm{CF}_{3} \mathrm{CO}_{2}\right)_{2}, \mathrm{CH}_{2} \mathrm{Cl}_{2}, \mathrm{rt}$.

\section{Results and discussion}

\section{Chemical synthesis}

The target conjugates were prepared following the synthetic scheme as depicted in Fig. 1. The starting materials 1,2,4-triazoles (3) were prepared in an efficient one-pot procedure including the cyanoimidation of aldehydes and cyclization. ${ }^{29}$ Following acylation of 3 to form 1,3-substituted-2-chloro- $\mathrm{N}-(1 \mathrm{H}$ 1,2,4-trizol-5-yl)acetamides (4), the sodium phenoates attacked 4 to provide $N$-(1,3-disubstituent-1H-1,2,4-triazol-5-yl)-2phenoxyacetamides (5). The reduction of 5 gave 1,3-disubstituent- $N$-(2-phenoxyethyl)-1 $H$-1,2,4-triazol-5-amines (6). Subsequently, the key step is the oxidative amination reaction $^{19,30,31}$ of 5 and 6 leading to their corresponding 4-triazolyl-1oxa-4-azaspiro[4,5]deca-6,9-dien-3,8-dione (1) and 4-triazolyl-1oxa-4-azaspiro[4,5]deca-6,9-dien-8-one (2) in moderate to high yields.

The formations reaction of $1 \mathbf{a}$ and $2 \mathbf{a}$ were taken as an example for optimization of reaction conditions of the oxidative amination using the previous work as ref. 19 and 31 The results (Table 1) show that copper(II), rhodium(II) and ruthenium(II) could be used as a catalyst for the amination of aromatic ether 5 and 6. Other metal complexes, such as those of $\mathrm{Mn}$ (II), $\mathrm{Co}$ (II) and $\mathrm{Fe}(\mathrm{II})$ displayed poor catalytic activities. At same time, we found that the yields increased inconspicuously when the loading of $\left[\mathrm{Cu}\left(\mathrm{CH}_{3}\right.\right.$ $\left.\mathrm{CN})_{4}\right] \mathrm{ClO}_{4}$ and $\mathrm{Cu}\left(\mathrm{CF}_{3} \mathrm{SO}_{2}\right)_{2}$ increased from $5 \%$ to $20 \%$. In addition, $\mathrm{PhI}(\mathrm{OAc})_{2}$ and $\mathrm{PhI}\left(\mathrm{CF}_{3} \mathrm{CO}_{2}\right)_{2}$ were employed effectively as oxidant for the oxidative amination of amides (5) and amines (6). Finally, the optimized conditions for the formation of triazolespirodienones $1 \mathrm{a}$ and $2 \mathrm{a}$ are in the molar ratio of $1: 2.5: 2.5: 0.1$

Table 1 Effect of catalysts and oxidants on the amination ${ }^{a}$
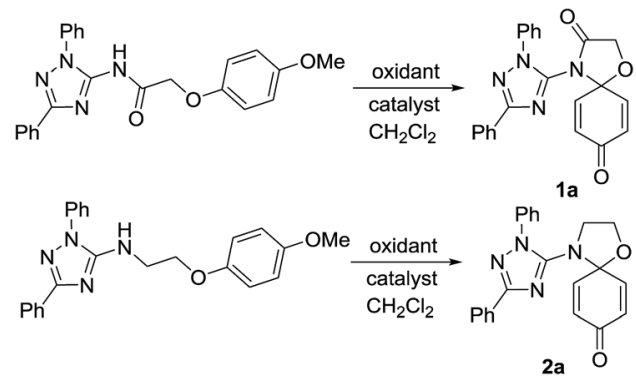

\begin{tabular}{|c|c|c|c|c|}
\hline \multirow[b]{2}{*}{ Entry } & \multirow[b]{2}{*}{ Catalyst } & \multirow[b]{2}{*}{ Oxidant } & \multicolumn{2}{|c|}{ Yield $^{b}(\%)$} \\
\hline & & & 1a & $2 a$ \\
\hline 1 & - & $\mathrm{PhI}\left(\mathrm{CF}_{3} \mathrm{CO}_{2}\right)_{2}$ & - & - \\
\hline 2 & $10 \% \mathrm{CuCl}_{2}$ & $\mathrm{PhI}\left(\mathrm{CF}_{3} \mathrm{CO}_{2}\right)_{2}$ & 32 & Trace \\
\hline 3 & $10 \% \mathrm{CuBr}_{2}$ & $\mathrm{PhI}\left(\mathrm{CF}_{3} \mathrm{CO}_{2}\right)_{2}$ & 32 & Trace \\
\hline 4 & $10 \% \mathrm{Cu}\left(\mathrm{CF}_{3} \mathrm{SO}_{3}\right)_{2}$ & $\mathrm{PhI}\left(\mathrm{CF}_{3} \mathrm{CO}_{2}\right)_{2}$ & 49 & 57 \\
\hline 5 & $10 \% \mathrm{Cu}(\mathrm{acac})_{2}$ & $\mathrm{PhI}\left(\mathrm{CF}_{3} \mathrm{CO}_{2}\right)_{2}$ & 36 & 28 \\
\hline 6 & $10 \% \mathrm{Cu}(\mathrm{OAC})_{2}$ & $\mathrm{PhI}\left(\mathrm{CF}_{3} \mathrm{CO}_{2}\right)_{2}$ & 30 & 22 \\
\hline 7 & $10 \% \mathrm{Cu}\left(\mathrm{CF}_{3} \mathrm{COCH}_{2} \mathrm{COCF}_{3}\right)_{2}$ & $\mathrm{PhI}\left(\mathrm{CF}_{3} \mathrm{CO}_{2}\right)_{2}$ & 36 & 29 \\
\hline 8 & $10 \% \mathrm{Cu}\left[\left(\mathrm{CH}_{3} \mathrm{CN}\right)_{4}\right] \mathrm{ClO}_{4}$ & $\mathrm{PhI}\left(\mathrm{CF}_{3} \mathrm{CO}_{2}\right)_{2}$ & 94 & 40 \\
\hline 9 & $5 \% \mathrm{Rh}_{2}(\mathrm{OAc})_{4}$ & $\mathrm{PhI}\left(\mathrm{CF}_{3} \mathrm{CO}_{2}\right)_{2}$ & 33 & Trace \\
\hline 10 & $5 \% \mathrm{Ru}(\mathrm{TTP}) \mathrm{CO}$ & $\operatorname{PhI}\left(\mathrm{CF}_{3} \mathrm{CO}_{2}\right)_{2}$ & 44 & Trace \\
\hline 11 & $10 \% \mathrm{Cu}\left(\mathrm{CF}_{3} \mathrm{SO}_{3}\right)_{2}$ & $\mathrm{PhI}(\mathrm{OAc})_{2}$ & 35 & 51 \\
\hline 12 & $10 \% \mathrm{Cu}\left(\mathrm{CF}_{3} \mathrm{SO}_{3}\right)_{2}$ & $\mathrm{PhI}=\mathrm{O}$ & 27 & Trace \\
\hline 13 & $10 \% \mathrm{Cu}\left[\left(\mathrm{CH}_{3} \mathrm{CN}\right)_{4}\right] \mathrm{ClO}_{4}$ & $\mathrm{PhI}(\mathrm{OAc})_{2}$ & 45 & 47 \\
\hline 14 & $10 \% \mathrm{Cu}\left[\left(\mathrm{CH}_{3} \mathrm{CN}\right)_{4}\right] \mathrm{ClO}_{4}$ & $\mathrm{PhI}=\mathrm{O}$ & 30 & Trace \\
\hline
\end{tabular}

${ }^{a}$ Substrate $(1 \mathrm{mmol})$, oxidant $(2.5 \mathrm{mmol}), \mathrm{Al}_{2} \mathrm{O}_{3}(2.5 \mathrm{mmol}) ; \mathrm{CH}_{2} \mathrm{Cl}_{2}$ as solvent, room temperature, 4 A molecular sieve. ${ }^{b}$ Isolated yield based on the amount of compounds 1a and 2a consumed. 
of substrate : $\mathrm{PhI}\left(\mathrm{CF}_{3} \mathrm{CO}_{2}\right)_{2}: \mathrm{Al}_{2} \mathrm{O}_{3}: \mathrm{Cu}\left[\left(\mathrm{CH}_{3} \mathrm{CN}\right)_{4}\right] \mathrm{ClO}_{4}$ for 1a or $\left(\mathrm{Cu}\left(\mathrm{CF}_{3} \mathrm{SO}_{2}\right)_{2}\right)$ for $\mathbf{2 a}$ at room temperature. Next, the reaction conditions of 1a and 2a were expanded to the formation reactions of all triazole-spirodienones 1 and 2, respectively. Thus, twenty four triazole-spirodienone 1 and 2 were obtained in 36-94\% yield (Fig. 1) from corresponding 2-phenoxy-ethyl-acet- $\mathrm{N}-2,3,5$-triazoleamides and 2-phenoxy-ethyl-ethyl- $N$-2,3,5-triazoleamines.

In entry, the effects of the substituents on the oxidative amidation reaction were noticed that the electron-donating groups sped the oxidative amination reaction of the aromatic ether derivatives (5 and 6) and the electron-withdrawing substituents resulted in moderate yields of the reaction, thereby, the reaction rates rely on the easy of oxidation of the substrate and the yields of triazole-spirodienone (1 and 2) are linked with the activity of the nitrogen sources, especially, the effect of $\mathrm{N}-\mathrm{H}$ dissociation energies of the nitrogen source.

To confirm the structures of triazole spirodienone conjugates, a single crystal of $\mathbf{1 p}$ was grown and analyzed by X-ray crystallography (the detailed crystal data are provided in the ESI $\dagger$ ). The ORTEP structure plot of 1p is displayed in Fig. 2.

The effect of substituent was investigated using different substituted aromatic ether derivatives as substrates under strictly identical condition. Interestingly, we notice that the reaction of these methoxy group substituent in the meta-position gave only two corresponding six-membered heterocyclic products $3 \mathbf{a}$ and $\mathbf{3 b}$ in $53 \%$ and $24 \%$ yield respectively (Scheme 1).

A mechanism is proposed in Scheme 2 for the oxidative amination reaction of the aromatic ether with $\beta$ - $\mathrm{NH}$-imidazole based on the mechanisms proposed originally for the amination by Antonchick ${ }^{32}$ and Chiba. $^{33}$ Initially ditrifluoroacetoxyiodobenzene reacts with the amide to give intermediate $\mathrm{A}$, which is then transformed into intermediate $\mathrm{B}$ through an oxidative insertion of $\mathrm{N}-\mathrm{I}$ bond by copper(II). The reductive elimination of intermediate $\mathrm{C}$ releases copper(I) salt, trifluoroacetic acid and iodobenzene, leading to final product 4-(1,3diphenyl-1H-1,2,4-triazol-5-yl)-1-oxa-4-azaspiro[4.5]-deca-6,9diene-3,8-dione (1). And the 4-(1,3-diphenyl-1H-1,2,4-triazol-5-

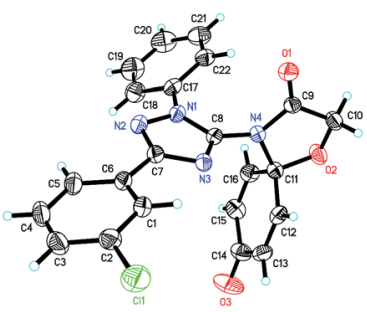

Fig. 2 ORTEP plot of molecular structure of $1 \mathrm{p}$

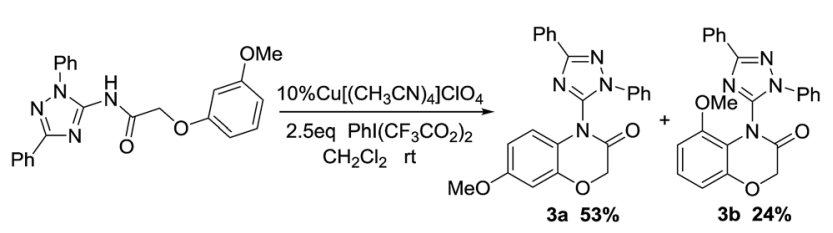

Scheme 1 The reaction results of $m$-methoxy substituted aromatic ether derivatives as substrates.

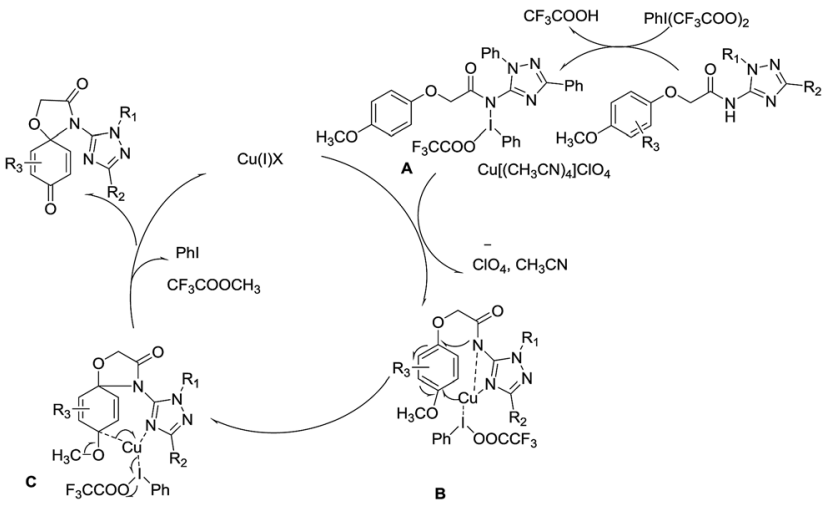

Scheme 2 Proposed mechanism for oxidative amination.

yl)-1-oxa-4-azaspiro[4.5]deca-6,9-diene-8-one (2) was obtained in similar mechanisms.

\section{Antiproliferation activity against a panel of cancer cell lines}

All of triazole-spirodienone conjugates ( 1 and 2 ) were examined for in vitro antiproliferation activities against a triple negative human breast cancer cell line, MDA-MB-231, an ER + human epithelial mammary carcinoma cell line, MCF-7, an invasive cervical cancer cell line, HeLa, and a metastatic non-small cell lung cancer cell line, A549. Table 2 displayed the $\mathrm{IC}_{50}$ values of 1 and 2 against these four cell lines. Moderate to high antiproliferative activities were observed in most of $\mathbf{1}$ and $\mathbf{2}$ derivatives, with $\mathrm{IC}_{50}$ values ranging from low nanomolar concentration to micromolar concentration. The triazole-spirodienone conjugates inhibited cancer cell growth in a dosedependent manner in all four cancer cell lines tested, and appear to exert a greater inhibitory effect on MDA-MB-231 cells in particular. Notably, 4-triazolyl-1-oxa-4-azaspiro[4,5]-deca-6,9dien-3,8-diones (1) were generally stronger cell growth inhibitors than the corresponding 4-triazolyl-1-oxa-4-azaspiro[4,5] deca-6,9-dien-8-ones (2). The only structural difference between 1 and $\mathbf{2}$ is the extra carbonyl group on 3-position of the spirodienone ring of $\mathbf{1}$, suggesting that introduction of a 3-one functional group at the spiro-ring increased the antiproliferation activity against cancer cells.

\section{Cytotoxicity towards MCF-10A normal mammary epithelial cells}

Seven of the most promising triazole-spirodienone conjugates (1a, 1d-f, and 1i-k) were selected for further evaluation of toxicity in normal mammary epithelial cells, MCF-10A. At 10 $\mu \mathrm{M}$, all the compounds were found to be significantly toxic towards MCF-10A cells, with toxicities moderating at a lower dosage of $1 \mu \mathrm{M}$. At both doses of 1 and $10 \mu \mathrm{M}$, doxorubicin, a widely used anticancer drug in clinic, was found to be much more toxic to normal cells than any of the selected triazolespirodienone conjugates (the detailed data see ESI $\dagger$ ). This observation is encouraging because the novel structural motif of triazole-spirodienone conjugates may offer a better separation of desired tumor toxicity and toxicity to normal cells. 
Table 2 Antiproliferation activity against cancer cell lines of 1 and 2

\begin{tabular}{|c|c|c|c|c|}
\hline \multirow[b]{2}{*}{ Compds } & \multicolumn{4}{|l|}{$\mathrm{IC}_{50}(\mathrm{nM})$} \\
\hline & MDA-MB-231 & HeLa & A549 & MCF-7 \\
\hline $1 \mathbf{a}$ & 20.3 & 93.9 & 288 & 40.7 \\
\hline $1 \mathrm{~b}$ & 16.8 & 12.2 & 69.0 & 231 \\
\hline $1 \mathrm{c}$ & 17.1 & 95.5 & 395 & 111 \\
\hline 1d & 4.56 & 21.0 & 4.18 & 62.1 \\
\hline $1 \mathrm{e}$ & 67.8 & 326 & 1800 & 31.4 \\
\hline 1f & 6.44 & 17.5 & 457 & 16.2 \\
\hline $1 \mathrm{~g}$ & 73.7 & 123 & 485 & 315 \\
\hline $1 \mathrm{~h}$ & 270 & 308 & 399 & 397 \\
\hline $1 \mathrm{i}$ & 1.37 & 62.9 & 203 & 43.3 \\
\hline $1 \mathrm{j}$ & 22.2 & 25.2 & 266 & 116 \\
\hline $\mathbf{1 k}$ & 27.7 & 10.0 & 268 & 88.8 \\
\hline 11 & 113 & 727 & 346 & 245 \\
\hline $1 \mathrm{~m}$ & 123 & 134 & 340 & 763 \\
\hline 1n & 157 & 107 & 484 & 1080 \\
\hline 10 & 453 & 381 & 31.1 & 465 \\
\hline $1 p$ & 0.80 & 45.3 & 25.2 & 4.11 \\
\hline $2 a$ & 470 & 123 & 357 & 694 \\
\hline $2 b$ & 555 & 126 & 698 & 442 \\
\hline $2 c$ & 60.6 & 976 & 465 & 843 \\
\hline $2 d$ & 170 & 979 & 809 & 846 \\
\hline $2 e$ & 309 & 753 & 1800 & 1530 \\
\hline $2 f$ & 684 & 996 & 1010 & 476 \\
\hline $2 \mathrm{~g}$ & 332 & 84.9 & 511 & 1100 \\
\hline $2 h$ & 141 & 1240 & 1190 & 442 \\
\hline
\end{tabular}

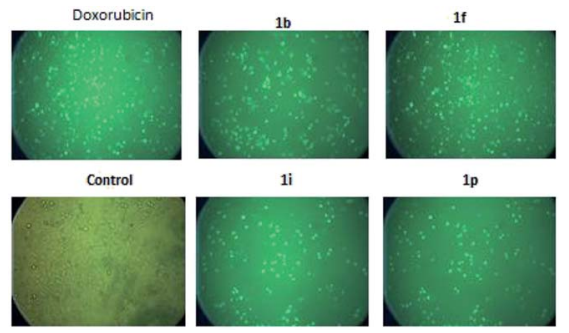

Fig. 3 Images of apoptosis induced by triazole-spirodienones conjugates, doxorubicin and vehicle control in HeLa cell lines.

\section{Apoptosis of HeLa cells}

We performed a caspase $3 / 7$ activation assay for compounds $\mathbf{1 b}$, 1i, 1f and 1p using fluorescence microscopy. HeLa cells were treated with four selected triazole-spirodienone conjugates at 1.0 $\mu \mathrm{M}$ or vehicle for 24 hours. In this assay, fluorescence signal was related to the degree of caspase $3 / 7$ activation and hence apoptosis induced by the treatment. As shown in Fig. 3, untreated cells showed minimal fluorescence, while treated cells exhibited significant increase in fluorescence (shown in green) indicating the prevalence of apoptosis of HeLa cells. These observations strongly suggest that triazole-spirodienone conjugates inhibited HeLa cells proliferation by triggering apoptosis.

\section{Conclusions}

Copper salt-catalyzed oxidative amination resulted in the formation of novel triazole-spirodienone conjugates, 4-triazolyl- 1-oxa-4-aza-spiro[4,5]deca-6,9-dien-3,8-diones (1) and 4-triazolyl1-oxa-4-aza-spiro[4,5]deca-6,9-dien-8-ones (2) which were evaluated for their antiproliferative activities against MDA-MB-231, HeLa, A549 and MCF-7 cell lines. Most of them showed moderate to high anticancer potency in the four cancer cell lines. Moreover, 4-triazolyl-1-oxa-4-azaspiro[4,5]deca-6,9-dien-3,8-diones (1) were found to exhibit superior anticancer activities compared to 4-triazolyl-1-oxa-4-azaspiro[4,5]deca-6,9-dien-8-ones (2). The

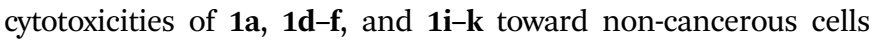
(MCF-10A) were measurable, but much less severe than that of doxorubicin, a known and widely used chemotherapy agent. Our study represents the first report on the preparation and biological evaluation of the novel triazole-spirodienone conjugates as potential anticancer agents. The analogs (1) are promising lead compounds on which further optimization of structure-activity relationships may lead to therapeutically useful new chemical entities for clinical treatment of cancer. Preliminary study on the mode of action suggests that the triazole-spirodienone conjugates inhibited cancer cell proliferation by triggering apoptosis, with more in-depth mechanistic studies under way in our laboratories.

\section{Acknowledgements}

This work was supported by the Sichuan University-Lu Zhou Strategic Cooperation Projects (No. 2013CDLZ-S18) (Ling He) and the NIH RCMI program at Xavier University of Louisiana through Grant 2G12MD007595-07 (G. Wang).

\section{References}

1 O. Tacar, P. Sriamornsak and C. R. Dass, J. Pharm. Pharmacol., 2013, 65, 157-170.

2 C. Parker, R. Waters, C. Leighton, J. Hancock, R. Sutton, A. V. Moorman, P. Ancliff, M. Morgan, A. Masurekar, N. Goulden, N. Green, T. Révész, P. Darbyshire, S. Love and V. Saha, Lancet, 2010, 376, 2009-2017.

3 C. Tan, H. Tasaka, K.-P. Yu, M. L. Murphy and D. Karnofsky, Cancer, 1967, 20, 333-353.

4 M. Tomasz and C. Mitomycin, Chem. Biol., 1995, 2, 575-579.

5 N. R. Bachur, S. L. Gordon, M. V. Gee and H. Kon, Proc. Natl. Acad. Sci. U. S. A., 1979, 76, 954-957.

6 M. T. Hoyt, R. Palchaudhuri and P. J. Hergenrother, Invest. New Drugs, 2011, 29, 562-573.

7 G. Kaur, R. P. Cholia, A. K. Mantha and R. Kumar, J. Med. Chem., 2014, 57, 10241-10256.

8 N. R. Bachur, S. L. Gordon and M. V. Gee, Cancer Res., 1978, 38, 1745-1750.

9 J. S. Bair, R. Palchaudhuri and P. J. Hergenrother, J. Am. Chem. Soc., 2010, 132, 5469-5478.

10 I. Gomez-Monterrey, P. Campiglia, C. Aquino, A. Bertamino, I. Granata, A. Carotenuto, D. Brancaccio, P. Stiuso, I. Scognamiglio and M. R. Rusciano, J. Med. Chem., 2011, 54, 4077-4091.

11 M. H. El-Dakdouki, N. Adamski, L. Foster, M. P. Hacker and P. W. Erhardt, J. Med. Chem., 2011, 54, 8224-8227. 
12 L. Trzoss, T. Fukuda, L. V. Costa-Lotufo, P. Jimenez, J. J. La Clair and W. Fenical, Proc. Natl. Acad. Sci. U. S. A., 2014, 111, 14687-14692.

13 P. Morales, D. Vara, M. Goméz-Cañas, M. C. Zúñiga, C. OleaAzar, P. Goya, J. Fernández-Ruiz, I. Díaz-Laviada and N. Jagerovic, Eur. J. Med. Chem., 2013, 70, 111-119.

14 A. A. Vieira, I. R. Brandão, W. O. Valença, C. A. de Simone, B. C. Cavalcanti, C. Pessoa, T. R. Carneiro, A. L. Braga and E. N. da Silva, Eur. J. Med. Chem., 2015, 101, 254-265.

15 E. N. da Silva Jr, B. C. Cavalcanti, T. T. Guimarães, M. d. C. F. R. Pinto, I. O. Cabral, C. Pessoa, L. V. CostaLotufo, M. O. de Moraes, C. K. Z. de Andrade, M. R. dos Santos, C. A. de Simone, M. O. F. Goulart and A. V. Pinto, Eur. J. Med. Chem., 2011, 46, 399-410.

16 C. Grasso, L. Larsen, M. McConnell, R. A. J. Smith and M. V. Berridge, J. Med. Chem., 2013, 56, 3168-3176.

17 X. Li, S.-L. Zheng, X. Li, J.-L. Li, O. Qiang, R. Liu and L. He, Eur. J. Med. Chem., 2012, 54, 42-48.

18 L.-M. Zhao, F.-Y. Ma, H.-S. Jin, S. Zheng, Q. Zhong and G. Wang, Eur. J. Med. Chem., 2015, 102, 303-309.

19 L. He, Y. Chen, J. Xie and J. Li, CN102285934, 2013.

20 Z.-K. Chen, Q.-Q. Yan, Z.-X. Liu, Y.-M. Xu and Y.-H. Zhang, Angew. Chem., Int. Ed., 2013, 52, 13324-13328.

21 Z.-K. Chen, Q.-Q. Yan, H. Yi, Z.-X. Liu, A.-W. Lei and Y.-H. Zhang, Chem.-Eur. J., 2014, 20, 13692-13697.

22 Y.-P. Hou, J. Sun, Z.-H. Pang, P.-C. Lv, D.-D. Li, L. Yan, H.-J. Zhang, E. X. Zheng, J. Zhao and H.-L. Zhu, Bioorg. Med. Chem., 2011, 19, 5948-5954.
23 F. Xu, Y. Jia, Q. Wen, X. Wang, L. Zhang, Y. Zhang, K. Yang and W. Xu, Eur. J. Med. Chem., 2013, 64, 377-388.

24 J. Lee, S. J. Kim, H. Choi, Y. H. Kim, I. T. Lim, H.-m. Yang, C. S. Lee, H. R. Kang, S. K. Ahn, S. K. Moon, D.-H. Kim, S. Lee, N. S. Choi and K. J. Lee, J. Med. Chem., 2010, 53, 6337-6354.

25 R. Romagnoli, P. G. Baraldi, O. Cruz-Lopez, C. Lopez Cara, M. D. Carrion, A. Brancale, E. Hamel, L. Chen, R. Bortolozzi, G. Basso and G. Viola, J. Med. Chem., 2010, 53, 4248-4258.

26 R. Kaur, A. R. Dwivedi, B. Kumar and V. Kumar, Anti-Cancer Agents Med. Chem., 2016, 16, 465-489.

27 R. J. Santen, H. Brodie, E. R. Simpson, P. K. Siiteri and A. Brodie, Endocr. Rev., 2009, 30, 343-375.

28 P. Goss, Breast Cancer Res. Treat., 1998, 49, S59-S65.

29 P. Yin, W.-B. Ma, Y. Chen, W.-C. Huang, Y. Deng and L. He, Org. Lett., 2009, 11, 5482-5485.

30 T. Dohi, A. Maruyama, Y. Minamitsuji, N. Takenaga and Y. Kita, Chem. Commun., 2007, 12, 1224-1226.

31 Y.-X. Deng, J.-P. Xie, W.-W. Zhang, P. Yin, J. Yu and L. He, Chem.-Eur. J., 2012, 18, 1077-1082.

32 A. P. Antonchick, R. Samanta, K. Kulikov and J. Lategahn, Angew. Chem., Int. Ed., 2011, 50, 8605-8608.

33 S. Chiba, L. Zhang and J.-Y. Lee, J. Am. Chem. Soc., 2010, 132, $7266-7267$. 